\title{
The phenomenology of experiencing poverty - an exploration
}

KAREN VAN DER MERWE*

\begin{abstract}
There is a plethora of research on poverty. Definitions of poverty are provided from various perspectives, reasons and causes for poverty are analysed, and descriptions are provided of the impact of poverty on adults and children. This article, however, tries to provide a unique view on the phenomenon of poverty: The focus is on a specific class of poor people, namely newly-impoverished people. It also provides a description and analysis of the very personal, subjective experience of poverty by this group of Afrikaans-speaking people. Various character strengths that may provide a sound foundation for psychosocial intervention programmes to re-launch newly impoverished people into economic independence are identified.
\end{abstract}

Keywords: Poverty, phenomenological research, character strengths

\section{Introduction and problem statement}

Poverty is a well-researched phenomenon and various perspectives on poverty are documented, for example economic, sociological, religious, and educational perspectives. In economic terms poverty is frequently described in terms of a poverty gap (Klasen 1997, Van Zyl 1997, Aliber, 2002). Sociological perspectives on poverty highlight deprivation such as no or limited access to education, employment, services, and health (Klasen 1997, Van Zyl, 1997), whilst social-psychological studies reveal societal stereotypes of poverty, the propensity of society to blame the victim (Chaftel 1997), and attributions for poverty (Cozzarelli, Abouchedid \& Nasser 2001; Bullock 1999). Poverty has also been studied from a developmental perspective (Harper, Marcus \& Moore 2003, Luthar, 1999, Garrett, Ng'andu \& Ferron, 1994), highlighting the effects of poverty on human development.

In the quest to understand poverty, various hypotheses regarding the causes of this phenomenon have been researched. Genetic and

\footnotetext{
* Ms Karen van der Merwe is lecturer, in the School for Behavioural Sciences in the Vaal Triangle Faculty of North-West University. She is currently researching the impact of God image and God concept on psychological wellbeing and gender role awareness.
} 
psychological causes (nature as opposed to nurture) include the cycle of deprivation (inadequate parenting, disadvantaged environment in which people are not equipped with adequate life-skills) and structural causes (the dynamic of social forces, which include policy making, and implementation as well as national and international economic forces) (Alcock 1997, Luthar, 1999). Various consequences of poverty have also been highlighted (Luthar 1999, Moore, 2003, Brusdal, 1990, Garrett, Ng'andu \& Ferron 1994).

Hills, Bradshaw, Lister, and Lewis, remark that research about poverty is generally done on poor people from a perspective in which they are seen as

passive victims, lacking agency, without views of their own and able only to testify to the impact of poverty in their lives $(2000,295)$.

This limitation was overcome in a comprehensive qualitative research project that focussed on poverty in seven provinces of South Africa. Gauteng and the Free State were excluded (May \& Norton, 1997). The project was aimed at providing a picture of the experience of poverty as analysed by the poor themselves. The participants in the study represented a sizable portion of South African society who had been disadvantaged by the apartheid ideology, policies and legislation that produced poverty and compressed social and economic class.

Since the advent of the new democracy, in 1994, comprehensive changes have occurred in South Africa. Legislation was adopted to eradicate the discrimination and inequalities of former times. This included changed labour legislation that resulted in new recruitment and appointment patterns. Many Whites who were previously advantaged by a sympathetic system had to compete in a changed labour environment, aimed at uplifting previously disadvantaged groups. Some Whites were illequipped and could not compete or cope in this new, for them, rather hostile environment. A specific group of poor people was identified as relatively unique regarding their situation and possibly their experience of poverty. These were people who became impoverished after having been economically active and relatively independent. Their new impoverished status resulted from various interconnected factors, which include the changed socio-political environment, personal crises, marital strife and family disintegration.

\section{Purpose statement}

This project aimed at listening to people living in poverty by acknowledging their expert insider views of the phenomenon and analysing their actual experience of poverty. The purpose of this study was to understand and systematically describe the essence of the experience of poverty of a group of Afrikaans-speaking destitute people in the Vaal Triangle, a region in 
Southern Gauteng, who have had to adjust to absolute poverty, no home, no food, and no job.

\section{Research approach}

It was decided to do a qualitative study in order to investigate the texture of people's very intimate experience of poverty. The researcher also believed that involving participants in the process of research as co-researchers would be empowering to the participants and the researcher and would contribute to the self-insight, personal growth and psychological wellbeing of all persons involved.

\subsection{Research design and methodology}

The decision to do a phenomenological psychological study was informed by the need for an alternative but complementary point of view (Giorgi, 1985), attempting to understand individuals living in poverty by entering into their field of perception in order to see life as they do. The focus was thus on the meaning of experiencing poverty for individuals (Creswell, 1997). In accordance with the leitmotif of phenomenology "to the things themselves" (Spiegelberg, 1984, 680) the study attempted to understand the subjective experiences of four people living in poverty. The aim was to obtain comprehensive data that would provide the basis for reflective structural analysis that portrays the essence of the experience of poverty (Moustakas, 1994).

Phenomenological research requires the researcher to bracket her own preconceived ideas about the phenomenon in order to understand it through the voices of the informants (Creswell, 1998, Giorgi, 1985). The foundation of understanding is that all behaviour is intentional, directed as something beyond itself. Understanding that the reality of an object is inextricably linked to a person's consciousness of that object, thus the reality of the object can only be perceived within the meaning of the experience of the individual (Creswell, 1998, Giorgi 1985).

Principles outlined in Giorgi (1985), Creswell (1998) and Moustakas (1994) regarding conducting phenomenological psychological research were followed. These are:

Description. The descriptions of naïve others were used. These original protocols were divided into statements, discriminated meaning units, or horizonalisation (Creswell, 1989).

Reduction. The descriptive units were transformed into clusters of meanings expressed in psychological concepts.

Search for essences. The above-mentioned transformations were finally interwoven to construct a general description of the phenomenon 
(Creswell, 1998). The level of analysis sought was general (Giorgi, 1985). Thus essences (structures) that are context-related were sought. These essences are not universal but relevant for a typical situation. Although essences are limited to the context, they still transcend the facts upon which they are based.

Steps listed in the methodology section were followed scrupulously in order to achieve good craftsmanship and precision which Henning et al. (2004) name as criteria for rating qualitative research as good scholarship.

Henning et al. (2004) refer to Kvale when stating that validation depends on good craftsmanship in an investigation, which includes continually checking and questioning. The process of continually questioning and checking proceeded on two levels: First, an independent coder (a fellow psychologist), as well as the researcher analysed the transcribed data to identify main categories and themes. Differences between the categories and themes identified by the researcher and independent coder were negligible, being rather differences in wording than in content. Thus inter-subjective validity (Giorgi, 1985) was achieved. On the second level, participants were individually asked what they saw as the the main themes' of their own descriptions, dialoguing with the researcher about their understanding, experience and emotional reactions (Henning et al., 2004). These two levels of dialogue (with an independent coder and with the participants) contributed to triangulation.

\subsection{Research context}

A shelter for destitute individuals and families was identified. A welfare organisation (the Suid-Afrikaanse Vrouefederasie: SAVF) runs the shelter. Residence is not permanent. The shelter is conceptualised as a place of safety where people can stay until they are able to secure a job and move on. Residents were previously independent and self-sufficient but recently became destitute due to various life events. They assist in the day-to-day running of the facility. Cooking, cleaning and other maintenance activities are performed by them. Individuals, industries or other organisations sometimes employ mostly men for day labour. Some of the residents have low-paying outside jobs (e.g. car guards) and are required to contribute part of their earnings to the running of the shelter. Various courses and programmes (material painting, sewing, leadership skills and religious meetings) are presented by the resident social worker and other community volunteers. Other needs provided for are education for the children and medical care of all the residents.

The research site was chosen amongst various options because it is run by a reputable non-governmental organisation (NGO) and managed by a qualified social worker. This facilitated easy access. The residents were people who had to make major adjustments, from being independent to being fully dependent on welfare. They had a unique experience of 
poverty, not previously having been so destitute. All except one of the residents were Afrikaans -speaking, which is the mother tongue of the researcher. As language and the finer nuances of the spoken word is the fundamental instrument for data gathering in this research this factor also influenced the choice of location.

Contact was made with the social worker of the shelter explaining the purpose of the research. It was agreed that access to the residents would be achieved by the researcher who would present a programme on parenting skills over a period of eight weeks. The social worker predicted that not all parents would attend due to the apathy many residents generally displayed. Only between eight and twelve people attended the parenting skills programme. Non-participating individuals therefore excluded themselves as possible participants in the research. Through workshop activities rapport was achieved and the research project was explained. After thorough discussion of the aims of the research with the workshop participants, an open invitation to participate was made. Four of the workshop participants volunteered to take part in the research. Interview times were scheduled to suit the programmes of the participants. These interviews were conducted during the last two weeks of the parenting skills programme.

\subsection{Sampling}

The criteria for sampling were that the individuals experienced the phenomenon of poverty (Creswell 1998) and were willing to participate in the research. The four people who responded (three women and one man) were participants in the workshop. This in itself attested to their involvement in life and their need to improve themselves as opposed to the apathy of some of the other residents. Each participant gave consent that the interviews could be recorded and the research results be made available in the public domain. Individual interviews were subsequently conducted:

whose purpose was to obtain descriptions of the life world of the interviewee with respect to interpreting the meaning of the described phenomena (Kvale, 1996:5, 6).

\subsection{Data collection and research question}

Individual unstructured interviews with participants were the instrument of research. The aim was to collect data to answer the following research question: From the perspective of the poor what is the essential structure of experiencing poverty? The question thus posed to each of the participants was: "How do you experience poverty? What does it mean to you to be poor?" 
Participants were allowed to express their experiences, thoughts and emotions. The researcher did not need to ask other questions but did on occasion provide minimal encouraging remarks. The duration of the interviews was between sixty and ninety minutes. The interviews were terminated when the data became saturated. In total six hours of interview data was collected, which is an acceptable amount of data for an interpretative phenomenological analysis (Madill, Gough, Lawton \& Stratton, 2005). The audio-taped interviews were transcribed and the process of analysis as explained in the methodology section followed.

\subsection{Data analysis}

Data analysis was conducted following the example of Giorgi (1985). The transcriptions of the interviews were a true reflection of each word used in the naïve description of the participants. These written accounts were subsequently divided in discriminated meaning units expressed in the participant's language. The next step was to express these meaning units more directly in psychological language and with respect to relevancy for the phenomenon of experiencing poverty. The researcher and the coder produced their descriptions independently. These descriptions were the basis for the formulation of specific descriptions of each participant's experience of poverty. Thereafter participants were individually consulted and dialogued with concerning the truth (validity) of these descriptions. As a result of this intensive interaction, questioning and clarifications, adjustments were made to accommodate new insights. The final step was to compare the different specific descriptions that reflected the actual experience of each participant in order to look for common themes, shared experiences and emotions and to identify a general structure of experiencing poverty.

\section{Results}

All participants had been recently impoverished to the point of destitution. None of the participants had a steady income for at least the previous six months. They had no sense or pre-knowledge of psychological or any other research on poverty. Their descriptions express their experienced meanings, which revealed the following dimensions:

\section{- Loss of control}

In each respondent's life there was a series of events that led to destitution. Each one had the experience of things spiralling out of control. Tanya describes her ordeal as 'First I lost all my furniture, then all the small items were stolen and my daughter was raped and later in another 
shelter everything else was stolen, even my mother's ring'. Karl could always provide for his family but he too lost control over circumstances: 'Poverty is a reality. It happens so quickly. If things go wrong it is a question of two or three months and then there is nothing (left)'. Each participant identified external factors as causes for their situation robbery, uncaring, irresponsible husbands, and becoming unemployed due to factors beyond their control.

\section{- Conscious choice to live}

The desperation of absolute poverty brought the option to escape through suicide and/or family murder. Each participant had at some stage or another to make the choice to live. Lena states 'It has brought me very near to suicide. I have many times thought about committing suicide and killing my children or just committing suicide and having them put in foster care where they at least will be fed.' They chose to regain control by choosing life. Karl stated, 'It will not help you to shoot or hang yourself. That is no solution. You have to get your life in order and find a job to get out of here.'

\section{- Loss of sense of self and new self-definition}

Loss of material possessions, life roles and a way of life result in a loss of sense of self. Not being able to provide in their needs and the needs of their children is devastating. Lena frequently begged for food. It implied loss of pride and dignity. According to Tanya, 'Poverty breaks you. You have to work very hard to regain your self-concept and sense of worth.' Not being able to provide a normal stable environment and having to explain their situation to their children proved extremely difficult. 'It is Christmas now. It is family time. There are organisations that give presents for all the children, but it is not the same. I always wore a Father Christmas suit and woke them up. Now this has been taken away from us.' Seeing their children suffer and being unable to change the situation were other concerns. 'Sometimes she (daughter) thinks because she suffers I don't feel anything. But as she feels hurt, I am hurt ten thousand times more.' (Lena)

A redefinition of self became necessary and was achieved in terms of values chosen. Values such as respect for others, equality, diligence and sympathy are held and these are the terms of their self-descriptions. 'I try to show everyone that I can work hard, that I can plan and make a success' (Karl) 'Poverty has taught me very good values. It has taught me to respect and appreciate things...and I sympathise with other people.' (Lena). However, staying true to these values and the core self thus represented did seem challenging at times, especially when they experience being looked down upon 'Sometimes you realise you have 
slipped and you think why should I care? The people who come here don't really see me, they don't really care.' (Wiida).

\section{- Abandonment by family}

Participants could not rely on their families to help them, neither materially nor emotionally. 'The moment when you are in this situation your family don't want anything to do with you. I think they are scared they must provide for you.'(Wiida) 'My brother promised to give me money for my birthday but I don't bargain on getting it. My sister gives me nothing. I let it roll off me. It's neither here nor there' (Lena).

\section{- Comparing self to others}

The participants felt that being poor places you in a special category. Poverty becomes a label that obscures the individual. 'People look down on you. Look at what you are wearing. Look at your hair. Why don't you work and look after your children. All those type of things' (Lena). Tanya sensed that affluent people expect to be treated with special respect: 'Sometimes people are haughty. You can feel and see if someone does not want to greet you.'

People who are involved in welfare work were frequently experienced by them as having an attitude of superiority that compounded their sense of being faceless. Wiida expresses it as follows: "The people who come here don't really see you; who and what you are. It does not matter to them where you are from and where you are going. You are just another hungry stomach that needs to be fed. That to me is very difficult.'

On the other hand the participants also compared themselves favourably to other residents in the shelter mostly in terms of their attitude towards life - grabbing every opportunity they were presented as opposed to others who had lost their self-confidence and sense of self-direction. 'Some of the women here are nervous wrecks. They don't do anything to fill their days. I am not such a sorry bundle of a person.' (Wiida)

Finally there was a comparison with people who have even less materially, which inspired them to gratitude. 'We think we suffer. There are others worse off. They don't even have a roof over their heads. We have been given a second chance.' (Karl)

\section{- Reflection and search for meaning}

Each participant reflected on the reasons for being in their current predicament. This prompted questions regarding where he/she went wrong and a search for meaning in his/her ordeal. What lessons were 
they supposed to learn? 'I let people walk over me. I did not speak my mind ... I have perhaps become hard. I don't easily believe people any more. I have become critical and I've learned to assess people' (Wiida).

All formulated some religious insights: God being the provider, protector, source of strength, and the teacher. Tanya expressed her hopeful search for meaning in the following terms: "There must be some reason why we are here. Perhaps God has a special plan for each one'. Some even saw their situation as a punishment for being self-centred. 'I believe God has shown me that I have only thought of myself. I think He wants me to work for Him' (Karl).

Linked to a finding of meaning is a positive, hopeful construction of the future. Each participant believed the future would be better than the present. 'It does not look so dark any more. I have a temporary job that might become permanent' (Wiida) 'Whether I am poor or not, I will not die...because I want to go on and secure a better future for me and my children. I will not sit still and expect others to find me a job or home.' (Lena)

\section{Discussion of phenomenological psychological findings}

Alcock $(1997,85)$ argues that simplified definitions and statistical measures necessarily overlook the complexities of the 'fine grains of the experiences of deprivation'. These findings shed light on these fine grains of the experience of poverty with regard to a specific group of newly impoverished people.

Society's stereotypical view of the poor as being deficient in some or other respect (Chafel, 1997) was experienced as depersonalising and demoralising by participants even to the point of them losing the will to strive to overcome their limiting situation. However, the study has identified various dimensions of experiencing of poverty that reflect personal strengths empowering the participants to try to rise above their circumstances.

These personal strengths include:

Constructive cognition. There is evidence of constructive cognition. Constructive cognition includes self-serving attributions and downward social comparison (Cantor, 2003). In as much as the participants compared themselves favourably to the other residents of the shelter who had given up, they were making self-serving attributions and downward social comparison. Reminding themselves of others worse off than themselves is another example of downward social comparison. Cantor (2003) describes constructive cognition as adaptive because it serves to mobilise a person's energy to try to do what they can in that circumstance. Participants were 
not giving up - they were motivated to take each opportunity presented for personal growth and development.

Optimistic explanatory style. Participants' beliefs that their circumstances were caused by external factors and that their futures would be better could be described as a more optimistic explanatory style. This is a cognitive personality variable that reflects how a person habitually explains bad events in terms of external (it's not only my fault, I lost my job, my husband left me), unstable (it's not going to last forever, the future is going to be better), and specific causes (it's because I made one bad decision) (Peterson and Seligman, 1984). Explanatory style presumably affects outcomes through its effects on one's expectations about the future controllability of events (Peterson \& De Vila, 1995). Each participant expected things to improve in future, not only due to their belief in God but also because they had grown as individuals and were willing to work hard and benefit from each opportunity given to them.

Self-reflection. Each participant's unique journey of self-discovery and search for meaning bears witness to their self-reflective capabilities. Caprara and Cervone (2003) describe this ability to reflect on own experiences, thoughts and emotions as the core of human strengths. Such consciousness enables people to contemplate and predict their own behaviour and that of others. Each participant grew in self-knowledge and developed a better understanding of others.

\section{Limitations of this study}

The context of the study may limit the applicability of the findings. As stated, the participants had become destitute recently. They are Afrikaans speaking and represent a specific culture. Thus, certain cultural values (western individualistic), religious values (a certain image of God) and a Protestant work ethic (characteristic of many Afrikaans-speaking people) colour their experience of poverty. The study also describes the experiences of people who are willing to help themselves, people who have not succumbed to the despair and helplessness that characterise many people living in poverty. These findings will not necessarily be applicable to all other poverty-stricken people.

\section{Conclusion and recommendations for future research}

The data point to the possibility of there being a window period of opportunity to re-launch newly impoverished people into economic independence. Participants still mostly had positive beliefs about themselves. This seems indispensable for recovery and regeneration (Saleebey, 2002). Stokols cautions that 
(C)onfinement to degraded and impoverished environments for extended periods of time may overwhelm individuals' best efforts to rise above these constraints, thereby fostering dispositions towards helplessness and despair (2003, 337).

Given this, it seems crucial that services at the shelter are aimed at facilitating the cultivation of human strengths and focused on throughput to avoid the 'satisfied poor phenomenon' which Olsen \& Schober $(1992,173)$ ascribe to resignation as coping strategy.

Psychosocial and community interventions at the level of preventing people who experience financially devastating life events need to be developed. These programmes need to capitalise on existing strengths and cultivate new personal strengths such as self-confidence, creativity, and capacity for hard work, self-determination, optimism and faith. Residents in such an environment would need to follow the programmes as soon as they arrive before satisfaction and a new sense of comfort sets in.

\section{Reference List}

Aspinwall, L. G. \& Staudinger, U. M. (Eds). (2003). A Psychology of Human Strengths. Fundamental Questions and Future Directions for a Positive Psychology. Washington: American Psychological Association.

Abouchedid, K. \& Nasser, R. (2001). Poverty attitudes and their determinants in Lebanon's plural society. Journal of Economic Psychology, 22, 271-282.

Alber, M. (2002). Poverty-eradication and sustainable development. Pretoria: HSRC Publication.

Alcock, P. (1997). Understanding Poverty. (2 $2^{\text {nd }}$ ed.). London: MacMillan.

Brusdal, R. (1990). Norwegian children's descriptions of the consequence of poverty and wealth. Journal of Economic Psychology, 11, 545 -556.

Bradshaw, J. \& Sainsbury, R. (Eds.). (2002). Experiencing Poverty. Burlington: Ashgate.

Bullock, H. E. (1999). Attributions for poverty: A comparison of middleclass and welfare recipient attitudes. Journal of Applied Social Psychology, 29 (10), 2059 - 2082.

Caprara, G. V. and Cervone, D. (2003). A conception of personality for a psychology of human strengths: Personality as an agentic, selfregulating system. In L.G. Aspinwall, \& U.M. Staudinger. (Eds.). A Psychology of Human Strengths. Fundamental Questions and Future Directions for a Positive Psychology (pp. 61-74). Washington: American Psychological Association. 
Cantor, N. (2003). Constructive cognition, personal goals and the social embedding of personality. In L.G. Aspinwall \& U.M. Staudinger. (Eds.). A Psychology of Human Strengths. Fundamental Questions and Future Directions for a Positive Psychology (pp. 49-60). Washington: American Psychological Association.

Chaftel, J. A. (1997). Societal images of poverty. Child and adult beliefs. Youth and Society 28 (4), 432-463.

Cozzarelli, C., Wilkinson, A. V. \& Tagler, M. J. (2001). Attitudes towards the poor and attributions for poverty. Journal of Social Issues, 57 (2), 207-227.

Creswell, J. W. (1998). Qualitative Inquiry and Research Design, Choosing among Five Traditions. Thousand Oaks: Sage Publications.

Garrett, P., Ng'andu, N. \& Ferron, J. (1994). Poverty experience of young children and quality of their home environments. Child Development, 65, 331-345.

Giorgi, A. (Ed.). (1985). Phenomenology and Psychological Research. Pittsburgh: Duquesne University Press.

Harper, C., Marcus, R. \& Moore, K. (2003). Enduring poverty and the conditions of childhood: Lifecourse and intergeneration poverty transmissions. World Development, 31 (3), 535-554.

Henning, E., van Rensburg, W. \& Smith, B. (2004). Finding your way in qualitative research. Pretoria: van Schaik.

Hills, J., Bradshaw, J., Lister, R. \& Lewis, J. (2002). The future of poverty research: Panel discussion. In J. Bradshaw \& R. Sainsbury (Eds.). Experiencing Poverty. Burlington: Ashgate. (pp. 289-297).

Klasen, S. (1997). Poverty, inequality and deprivation in South Africa: An analysis of the 1993 SALDRU Survey. Social Indicators Research 41, 51-94.

Kvale, S. (1996). InterViews. Introduction to Qualitative Research Interviewing. Thousand Oaks: Sage Publications.

Luthar, S. S. (1999). Poverty and Children's Adjustment. New Delhi: SAGE Publications.

Madill, A., Gaugh, B., Lawton, R. \& Stratton, P. (2005). How should we supervise qualitative projects? The Psychologist, 18 (10), $616-618$

May, J. \& Norton, A. (1997). “A difficult Life”. The perceptions and experiences of poverty in South Africa. Social Indicators Research 41, 91-118. 
Moore, K., Harper, C., \& Marcus, R. (2003). Enduring poverty and the conditions of childhood: Life course and intergenerational poverty transmission. World Development 31(3), 535-554.

Moustakas, C. (1994). Phenomenological Research Methods. Thousand Oaks: Sage Publications.

Olsen, G. I. \& Schober, B. I. (1993) The satisfied poor. Social Indicators Research 28,173-193

Peterson, C. \& De Villa, M. E. (1995). Optimistic explanatory style and perceptions of health problems. Journal of Clinical Psychology, 51(1), $128-132$.

Peterson, C. \& Seligman, M. E. P. (1984). Causal explanations as a risk factor for depression: Theory and evidence. Psychological Review, $91,347-374$.

Saleebey, D. (Ed.). (2002). The Strength Perspective in Social Work Practice. ( $3^{\text {rd }}$ ed.). Boston: Allyn and Bacon.

Shek, D. T. L. (2002). Chinese adolescents' explanations of poverty: The perceived causes of poverty scale. Adolescence, 37(148), 789-803.

Winter.

Spiegelberg, H. (1984). The Phenomenological Movement. A Historical Introduction. ( $3^{\text {rd }}$ revised and enlarged edition) The Hague: Martinus Nijhoff Publishers.

Stokols, D. (2003). The ecology of human strength. In L.G. Aspinwall \& U.M. Staudinger, (Eds.). (2003). A Psychology of Human Strengths. Fundamental Questions and Future Directions for a Positive Psychology (pp. 331-344). Washington: American Psychological Association.

Van Zyl, R. (1997). Armoede in Suid-Afrika. Aambeeld, 25, 7-9. 


\section{ADVANCE CONFERENCE INFORMATION: $5^{\mathrm{TH}}$ IWHA CONFERENCE, "PASTS AND FUTURES OF WATER", 13 TO 17 JUNE, 2007}

The International Water History Association (IWHA) will hold its $5^{\text {th }}$ biennial conference from 13 to 17 June, 2007 in Tampere, Finland with the general theme "Pasts and Futures of Water". The event is co-organized and hosted by University of Tampere (Dept. of History) and Tampere University of Technology, TUT (Institute of Environmental Engineering and Biotechnology, IEEB).

The major themes of the conference are:

(i) Water and the City

(ii) Water, Health and Sanitation

(iii) Water, Food and Economy

(iv) Water history and the Future of Humanity.

First Announcement will be published in June 2006 and can be viewed at: www. envhist.org. Proposals are to be sent by 15 Oct 06.

For possible enquiries: victor.pal@uta.fi, eija.vinnari@tut.fi.

The International Water History Association (IWHA) is the leading global organization on water history. Previous Biennial IWHA Conferences were held in Bergen, Norway, at the Bibliotheca Alexandrina, Egypt, and at UNESCO Headquarters, Paris, France. The Association deals with water history in all its aspects bringing together historians, geographers, engineers, archaeologists, anthropologists, and water managers. IWHA is committed to bridge the gap between academics and policy makers, and strives to ensure representation from all world regions. To become a member and enjoy the benefits of IWHA membership visit www.iwha.net 